\title{
Increasing the competitiveness of e-vehicles in Europe
}

\author{
Erik Figenbaum $^{1} \cdot$ Nils Fearnley $^{1} \cdot$ Paul Pfaffenbichler $^{2} \cdot$ Randi Hjorthol $^{1}$ • \\ Marika Kolbenstvedt ${ }^{1} \cdot$ Reinhard Jellinek $^{3} \cdot$ Bettina Emmerling $^{3}$. \\ G. Maarten Bonnema ${ }^{4,5}$ - Farideh Ramjerdi ${ }^{1}$ • Liva Vågane ${ }^{1} \cdot$ Lykke Møller Iversen $^{6}$
}

Received: 19 December 2014 / Accepted: 3 August 2015/Published online: 20 August 2015

(C) The Author(s) 2015. This article is published with open access at SpringerLink.com

\begin{abstract}
Introduction This paper is concerned with incentives for the take-up and use of e-vehicles that are in place in different European countries. Especially, it analyses Norway and Austria, in order to establish and understand factors influencing the competitiveness of e-vehicles and potential market penetration. Norway currently enjoys the world's largest take-up of electric cars per capita, achieved through an extensive package of incentives. Austria has used the concept of Model Regions with government support to stimulate market introduction. So far, this has been a less effective approach.

Methods The paper brings in and combine analyses of national travel survey data and web surveys to e-vehicle owners and non-e-vehicle owners. It considers socio-economic factors including convenience and time savings due to e-vehicle policies.

Results Analysing national travel surveys, we find a considerable potential for e-vehicles based on people's everyday travel. Social networks play a crucial role in spreading knowledge about this relatively new technology. The take-up of
\end{abstract}

This article is part of the Topical Collection on Driving Societal Changes towards an Electro-mobility Future

Nils Fearnley

naf@toi.no

Institute of Transport Economics, Gaustadalleen 21, 0349 Oslo, Norway

2 Vienna University of Technology, Vienna, Austria

3 Austrian Energy Agency, Vienna, Austria

4 Buskerud and Vestfold University College, Drammen, Norway

5 University of Twente, Enschede, The Netherlands

6 The Danish Road Directorate, Copenhagen, Denmark battery electric vehicles correlates relatively closely with the user value of e-vehicle incentives. The fiscal effects of evehicle incentives are non-trivial - especially in the longer run. The cost of lifting a new technology into the market by means of government incentives is significant. We point to the importance of a strategy for the gradual phasing out of evehicle policies in countries with large incentives when the cost of vehicles goes down and the technology improves.

Conclusions Successful market uptake and expansion of electric vehicles requires massive, expensive and combined policies. Central government backing, long term commitment and market-oriented incentives help reduce the perceived risk for market players like car importers and allow the e-vehicle market to thrive. For countries with low e-vehicle market shares the potential is promising. Battery electric vehicles are already a real option for the majority of peoples' everyday trips and trip chains. However, their relative disadvantages must be compensated by means of incentives - at least in the initial market launch phase. Diffusion mechanisms play a sizeable role. The lack of knowledge in the population at large must be addressed.

Keywords Electromobility · Incentives · Transport policy · Electric vehicles

\section{Background and introduction}

The 2011 EU White Paper on Transport sets ambitious goals for phasing out conventionally fuelled cars in cities. Take-up and expansion of electric vehicles (e-vehicles, or electromobility) are one way to achieve this, as proposed by, i.a., the European Green Cars Initiative, the EU Action Plan on Urban Mobility, and the European alternative fuels strategy. Although several countries have set sales and stock targets 
for electrification as part of their climate policy, the number of such vehicles in use is very limited in most countries. A report from the Electric Vehicles Initiative [7] shows that their 15 members have an electric vehicle stock of $0.02 \%$ while the target is $2 \%$. This discrepancy is part of the background for ERA-net's Electromobility+ programme, which funds $20 \mathrm{Eu}-$ ropean projects on this topic. One of these is the project, "Competitive Electric Town Transport" (Compett), which is the source for this paper. ${ }^{1}$

In this paper, the term electric vehicle (EV) is used and understood as battery electric vehicles (BEV) that are only powered by electricity, including Extended Range Electric vehicles. Hybrid Electrical Vehicles and Plug in Hybrid vehicles are not pure EVs. The most widely used alternative is the ordinary internal combustion engine (ICE), which usually runs on conventional fuels like petrol and diesel.

The recent years have seen substantial developments in the EV markets globally. The price of EVs has gone significantly down in real prices. Figure 1 illustrates how net prices have fallen steadily during the period 2009-14 for two typical BEV classes as represented by the Think City/Mitsubishi i-Miev, which are of relatively equivalent category, and the Nissan Leaf. This development in price reflects a real development in prices of relevance for Europe, since BEVs have been exempted from Norwegian VAT and registration tax throughout this period. At the same time, the new models are better equipped and enjoy better warranties and dealer coverage. Further, a large variation of vehicles is now available. Back in 2009, there was only one real battery passenger car alternative market, the "Think".

The introduction of a new technology and departure from ICEs could require large subsidies and investments as well as a political commitment [30], a situation more generally found for environmental technology [21,36].

This paper is concerned with incentives for the take-up and use of e-vehicles that are in place in different European countries and to what extent they affect market shares of vehicle sales and vehicle fleets. A focus is placed on the user value of individual incentives, as well as their impact on public budgets. Although highly relevant, it is not within this paper's scope to consider the consequences on the total level of traffic, nor to present a full economic welfare assessment of EV policies.

Norway currently stands out as the world's largest evehicle market as measured per capita. Therefore, Norwegian policies and their impact are of particular interest for this paper. The analysis includes socio-economic factors as well as convenience and time savings due to e-vehicle policies. On the government side, the fiscal effects of e-vehicle incentives are significant. The cost of lifting a new technology into the

\footnotetext{
${ }^{1}$ In particular: Hjorthol [16], Hjorthol et al. [17], Figenbaum and Kolbenstvedt [11, 12], Figenbaum et al. [10, 13], and Fearnley et al. [9].
}

market is considerable. Therefore, this paper highlights the need for a strategy for the phasing out of e-vehicle policies.

In this paper, we will investigate policy options for increasing the share of EVs. For that, we will mainly concentrate on the Norwegian situation. Yet, as Compett also includes Austria, we make an excursion there and make some comparative assessments of the two countries.

This paper brings in and combines analyses of the 2009 Norwegian National Travel Survey (NTS), two web surveys among e-vehicle owners and non-e-vehicle owners, respectively, and an analysis of socio-economic factors including convenience and time savings due to e-vehicle policies. It also builds on work within the Compett project to further develop a dynamic car fleet and propulsion technology model called Serapis $[14,27,28,31]$. Serapis produces time series data about the number of vehicles by propulsion technology as a result of policy interventions like EV incentives, and calculates environmental and economic indicators for the evaluation of these policies.

The remainder of this paper is organised as follows. The next section provides an overview of European incentives and market shares. Section 3 presents theory and empirical evidence for market diffusion of EVs and presents key findings of an analysis of NTS data, which suggests the size of the potential for EVs. Section 4 goes more into detail of the Norwegian incentives and their effect on market shares and presents findings of the two web surveys. Section 5 provides a socio-economic assessment of these policies. Finally, section 6 draws conclusions and policy recommendations.

\section{European incentives and market shares}

The market for EVs has increased between 2010 and 2014 in most countries, but most profoundly in Norway, which currently is the European leader in EV adoption both in absolute numbers and in market share (Fig. 2 for BEVs and Table 1 for all EVs). The market share of sales in the first half of 2014 was close to $13 \%$ in Norway, with the Netherlands and Estonia as the next countries, relatively far behind with market shares around $1 \%$.

Table 1 also presents the various EV incentives that are in place in a selection of European countries. The table is an approximation and a snapshot only, because several subsidies come and go, are only in place in certain regions or cities, are limited in time and value, and so on. The most widely used incentives in this selection of European countries are registration tax exemption, annual vehicle tax exemption and purchase subsidy/grant. In some countries, these are rebates rather than exemptions. It is worth noting that the highest market shares, especially in Norway and Iceland, are associated with non-financial incentives as well, like bus lane access, and nontax incentives like free street parking. This observation 
Fig. 1 Typical price development of EVs in the Norwegian market. Net costs, fixed 2013 prices. $($ NOK $1=$ $€ 0.12$ at time of writing)

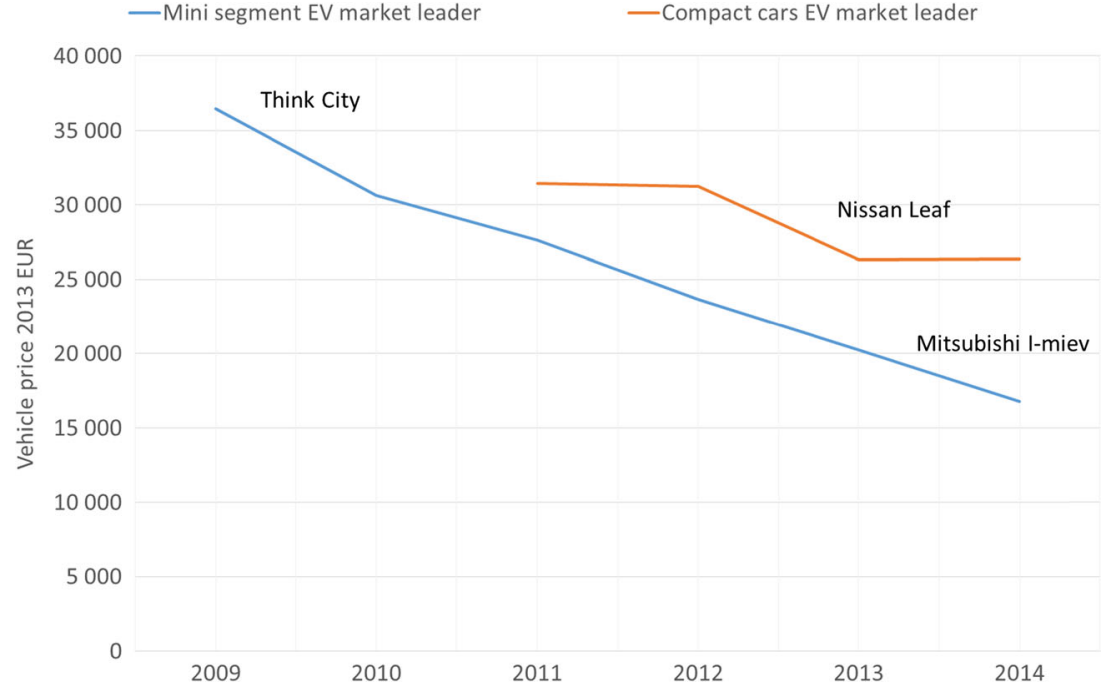

supports the findings of Moch and Yang [24] who compare incentives and market share in different countries and show that there are limits to what can be obtained by fiscal incentives alone.

There is a clear tendency in Table 1 that more incentives are associated with higher EV market shares. Norway, in particular, stands out with the highest market share and the widest array of incentives. These are presented and discussed in greater detail later in this paper.

According to Pan et al. [25], cities are more innovative, having universities, more international contacts and more people and interpersonal communication networks. Another aspect is the increased visibility with more people seeing the EV in use, especially so in Norway with special signs for EVs. The diffusion pattern for EVs in Norway seems to follow the normal path. Figenbaum and Kolbenstvedt [12] show that the pioneer areas of electromobility were found in the larger cities and their vicinities and that this was clearly related to incentives making commuting cheaper as well as timesaving.

\section{Market potential}

\subsection{From early adopters to early majority}

EV uptake and growth potential in the markets depend, firstly on the early adopters and future diffusion into the rest of the market and, secondly, on the proportion of daily trips and trip chains that possibly can be made within EVs' limited range
Fig. 2 2010-2013 BEV total sales (left axis) and share of total market sales (right axis) in different countries. Sources: ACEA [1], local statistical services, internet fora, and industry monitors

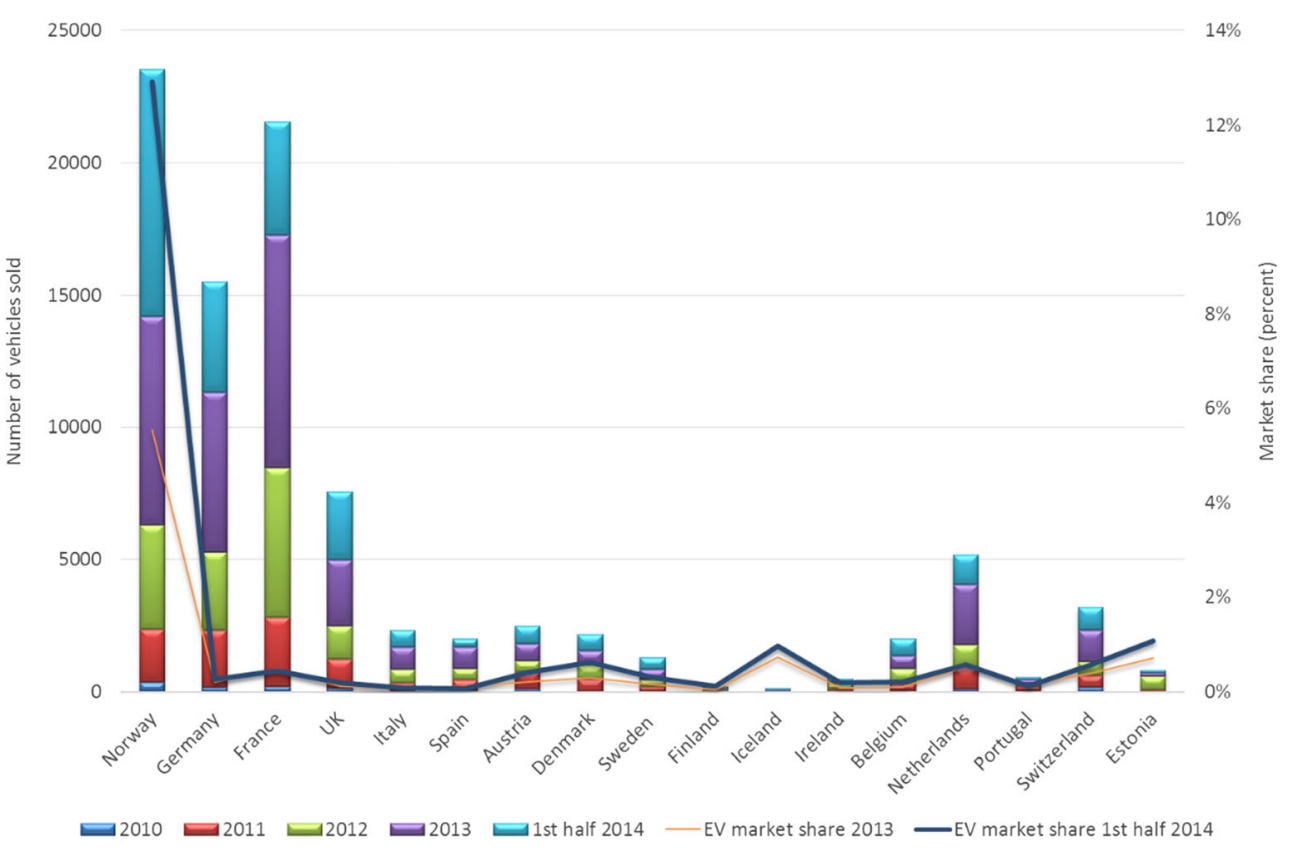


Table 1 EV market shares and incentives in a selection of countries

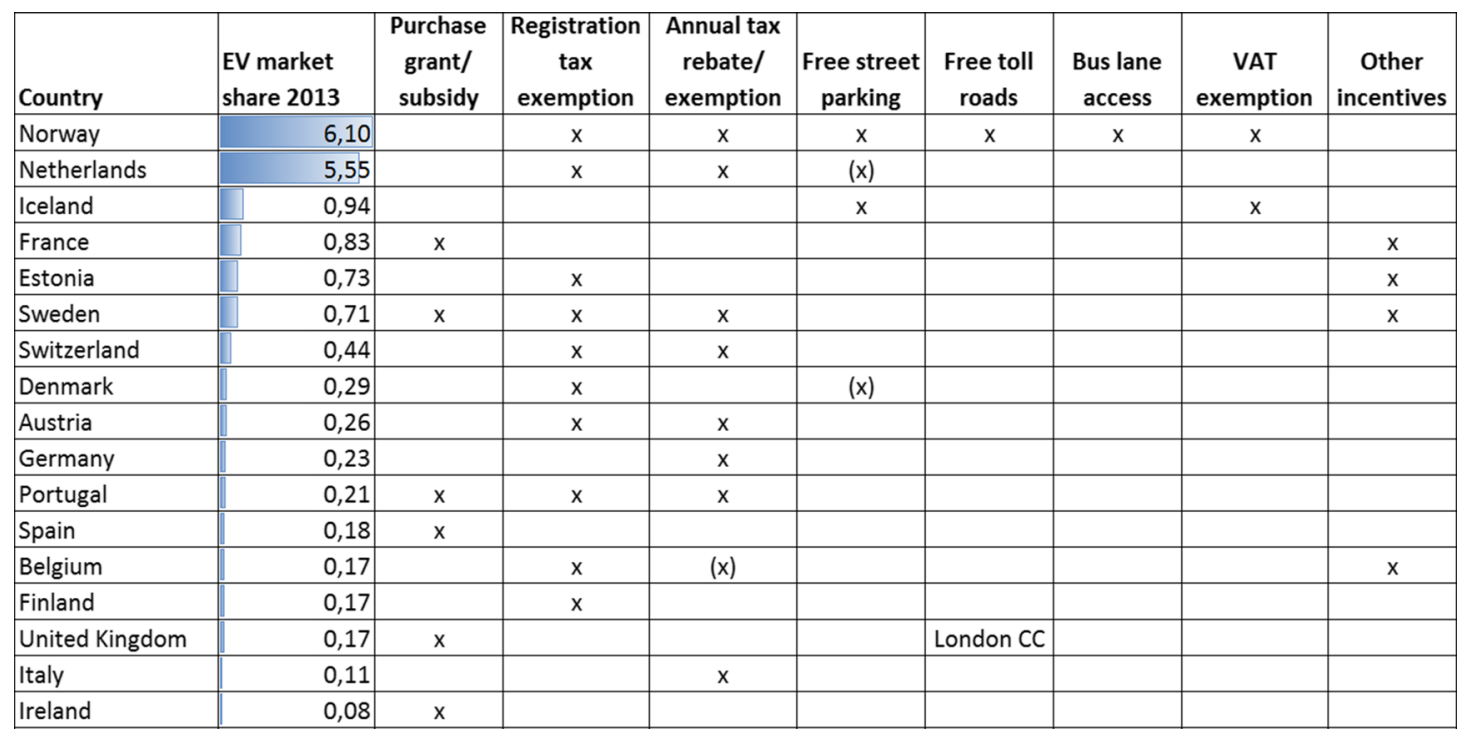

Sources: Market shares: Shahan [34]. Incentives: Wikipedia [37]; and ACEA [1]

For some countries, these sources are in conflict. E.g., Wikipedia does not mention the "Super green car premium" in Sweden, annual circulation tax exemption in Portugal, and Flanders registration tax exemption and annual tax benefits in Belgium, all of which are mentioned in ACEA [1]

and battery charging needs and, thirdly, on the relative advantage of EVs compared with traditional vehicles.

Different actors and decision makers will react differently to new products. It is therefore essential that some people are willing to try out new technologies. Rogers [33] distinguishes between five groups of users of innovations with different socio-economic and personal characteristics and communication behaviours: Early users (Innovators); Early adopters; The early majority; The late majority; and Laggards. Using new environmental technology can often have rebound effects and involve costs for the users. Environmental innovations cannot usually develop into a large market without parallel public incentives $[12,13]$.

Studies of early adopters of EVs indicate common sociodemographic characteristics across countries. The early adopters are relatively young, a majority are men, they have high education and income, and belong to households with more than one car [5, 6, 29, 32, 35]. The majority also lives in, or in the vicinity, of larger cities. Figenbaum et al. [13] evaluate the Norwegian market and find that the largest potential for further expansion lies in the early majority, who considers buying an EV next time or who haven't made up their minds, and the late majority, who still don't consider the EV option. The early majority group has, more or less, the same sociodemographic characteristics as potential car buyers in general. The suggested positioning of the groups indicates a continuing positive diffusion process in Norway.

Looking at diffusion as an interplay between technology and society (cf. [33]), understanding the communication processes is important in order to assess the market potential of an innovation. In their study of factors influencing EV diffusion,
Figenbaum and Kolbenstvedt $[12,13]$ look at the importance of social networks. Social network is here defined a social structure made up of a set of ties between social actors (individuals, groups, organizations), c.f. Parsons [26]. The possible importance of social networking sites is included the media category. They found that on average $36 \%$ of the EV owners have friends who bought an EV after they told them about their experience and $34 \%$ that now consider buying an EV. The latter group represents a potential for the EV market. Those who live in the city or close to the city, have more friends that have bought EVs after being informed, compared to those who live further away. The latter group has more friends considering buying, i.e. a greater potential. This is seen in the Norwegian EV market growth that, relatively seen, was greatest in smaller cities and rural areas the last year. The potential growth in these areas will easier be realised when the technological developments secure a longer EV range, more charging stations are at hand and an increasing amount of information about the EVs energy efficiency and other assets is disseminated through media (including websites) and social networks (cf. Figenbaum et al [10, 13]).

\subsection{Daily travel lengths and stop pattern}

Range anxiety (the fear of being stranded due to a depleted battery) is ubiquitous and has been a major barrier for EV diffusion (cf. $[3,10,11])$. However, the range of new EVs and capacities of batteries keep increasing. For the purpose of analysing EV potential, the Compett project (cf. section 1), and in particular Hjorthol et al. [18], used data from the 
Norwegian 2009 National Travel Study (NTS 2009) to describe the general travel pattern and length of trips in the population.

In Hjorthol et al. [18] we applied a range limit of $80 \mathrm{~km}$ in winter (October-March) and $120 \mathrm{~km}$ during summer (AprilSeptember). These limits were set with an eye to the owners, who usually prefer a safety margin of $20 \%$ of the battery, in order to account for some reductions as the vehicle ages, and in order to account for increased vehicle drag, losses and heating requirement in the winter (cf. [13]). (Tesla Model S, which makes up about $15 \%$ of the Norwegian EV fleet, is not limited by these range limits.)

The Norwegian NTS 2009 shows that the population make on average 3.3 trips per day, all moods included. The average trip is $12.0 \mathrm{~km}$ and lasts for $24 \mathrm{~min}$, and the average length travelled per day per person is $42.1 \mathrm{~km}$. A large proportion of daily trips is short. Only $27 \%$ are $10 \mathrm{~km}$ or longer. Relating this to the critical range of an EV, only $2.7 \%$ of the car trips are longer than $80 \mathrm{~km}$ (winter limit), and $1.4 \%$ are longer than $120 \mathrm{~km}$ (summer limit). Looking at the total car driving distances made as driver, only $5.3 \%$ are longer than $50 \mathrm{~km}$. Studying the total distance as a car driver on an average day in NTS, as many as $88 \%$ have no need for recharging [18].

However, trips need to be analysed in connection, in trip chains. The single trips are not isolated entities. They add up, and while a trip itself may be short, it could be part of a longer trip chain, with a possible need of recharging. Looking at daily car trip chains, only $8 \%$ are longer than $80 \mathrm{~km}$ and only $4 \%$ of them are longer than $120 \mathrm{~km}$. Work related trip chains are longer than the average tip chain [18].

On an average day, $12 \%$ of Norwegians exceed the range limits. In these situations, it is necessary to recharge in order to use an EV. Recharging can be done during the day if the stops are long enough and the conditions are suitable with access to at least an ordinary electric socket for normal charging (typically home or work). Of the relatively few car drivers in Norway who exceed the range limit per day, a majority has stops during the day giving a good potential for recharging. Between 24 and $29 \%$ stop at home between 1 and $5 \mathrm{~h}$ during an average day and 20-40\% have a long stop at work of more than $5 \mathrm{~h}$, both sufficient for full or partial charging. In addition, about $10 \%$ can park at a designated parking area, and have a potential for some recharging there.

In Austria, the average trip in 1995 was $9.5 \mathrm{~km}$ and lasted for $23 \mathrm{~min}$, and the average length travelled per day per person was $29 \mathrm{~km}$. In Lower Austria the average length is $43 \mathrm{~km}$ in 2008. Trips are short also here: $6 \%$ of the trips in Lower Austria 2003 and $2 \%$ in Vorarlberg 2008 exceed 50 km [18].

\subsection{Long trips to leisure homes}

A separate analysis of the long trips $(100 \mathrm{~km}+)$ in Norway from the 2009 NTS shows that the majority of these trips are connected to holidays and leisure activities, and most of them are done by car. People living in the surrounding municipalities of the capital, Oslo, are those who have the highest number of long car trips in the country. Men have more long car trips than women. People in their middle ages, those with high household income, those with three or more cars, and work more than $40 \mathrm{~h}$ per week have most frequent long car trips.

About $40 \%$ of the Norwegian population own or have access to a leisure home/cottage/summer house. People living in the large cities and the surrounding areas have the highest ownership. On average people drive to their cottage 14 times a year. The estimated average distance to the holiday houses is $150 \mathrm{~km}$, but one third have less than $50 \mathrm{~km}$ to the cottage, and further $20 \%$ have a distance between 50 and $100 \mathrm{~km}$. This is within the range of most EVs in the summer season. However, $40 \%$ of the cottages do not have electricity installed, thus hampering the return trip.

A substitution of an EV for a traditional car, considering transport to the holiday house, is primarily a problem for a majority of those living in the metropolitan area of Oslo, who have the longest distances to their summerhouse, and primarily so during winter time. Recharging on the way can solve the problem, but during holiday seasons, many people will be on their way simultaneously and might create a capacity problem at charging stations.

\section{Electric mobility developments in Norway and Austria}

\subsection{Norway}

Norway has, as stated above, the worldwide largest number of EVs per capita. The policy basis leading to this result has evolved over the years. In the early 1990s, the target of the policies was to make it possible to test and evaluate environmental technology by removing the new vehicle sales tax [23]. Cities soon wanted faster market development and the exemption from toll roads (in the beginning around Oslo) was introduced in 1997 and free parking in 1999 [2]. In the period around the turn of the century the focus shifted towards supporting the emerging national electric vehicle industry, such as Think, which was acquired by Ford in 1999 [20]. The exemption from VAT was introduced in order to help boost the home market [4]. In 2003, EVs gained access to the bus lanes around Oslo. The Norwegian Public Roads Administration wanted to remove private minibuses from the bus lane, thereby opening up a window of opportunity for EV lobbyists [11]. However, Think was unable to produce EVs, as Ford had sold the company, PureMobility, another Norwegian company, produced a small hand built EV. Second hand EVs were imported from countries that had abandoned their EV activities, such as France and the US, to meet the demand 
from bus lane users in the Oslo area [11]. Towards 2010, the EV policy focus also shifted towards achieving greenhouse gas emission reduction. Think was reborn and a support program for charging infrastructure and reduced rates on ferries was introduced in 2009. The aftermath of the financial crisis in 2009 led to a downfall of the Norwegian EV industry. Original Equipment Manufacturers (OEMs) launching their EVs from late 2010 could exploit two decades of efforts to establish EV incentives. The sharp increase in the fleet after 2010 is due to more and more OEM EVs being launched. The prices of EVs were at the same time going down, cf. Fig. 1. The developments in incentives, supply side and market penetration are combined in Fig. 3.

When looking at the different Norwegian EV incentives, Figenbaum et al. [13] used a division into three different types of incentives: 1) fiscal, 2) direct, and 3) incentives giving relative advantages to compensate for drawbacks. This again is based on Figenbaum and Kolbenstvedt [11]. Parts of this elaboration is reproduced in Table 2.

Norway is in many ways unique. It is wealthy, distances are long, it is mountainous, and winters are cold. While the former might promote EV usage, the latter three limit their application. Expansion outside of the major urban areas and commuting distances necessitates a suitable charging infrastructure. This is under (rapid) development led by both a nationally funded organisation (Transnova, a government body, which provides financial support to the establishment of public charging facilities; in 2015 Transnova merged with ENOVA) and local and private initiatives. At the time of writing, there are about 5000 charging outlets (nobil.no) across Norway, of which about a hundred are fast charge stations. Special attention has been paid to developing fast chargers along the main
Table 2 Figenbaum et al. [10, 13]'s evaluation of EV Norwegian incentives

\begin{tabular}{lll}
\hline Incentives & Introduced & $\begin{array}{l}\text { Importance } \\
\text { for uptake }\end{array}$ \\
\hline $\begin{array}{l}\text { Fiscal incentives - reduce purchase price/ } \\
\text { yearly cost gives competitive price }\end{array}$ & & \\
$\quad$ Exemption from registration tax & $1990 / 1996$ & + \\
VAT exemption & 2001 & ++ \\
Reduced annual vehicle license fee & $1996 / 2004$ & + \\
$\quad$ Reduced taxable benefit on company cars & 2000 & 0 \\
Direct subsidies to users - reducing & & \\
$\quad$ usage costs and range challenges & & \\
Free toll roads & 1997 & ++ \\
Reduced rates on ferries & 2009 & 0 \\
Financial support for charging stations & 2009 & + \\
Fast charge stations & 2011 & + \\
Reduction of time costs and giving & & \\
relative advantages & & \\
Access to bus lanes & $2003 / 2005$ & ++ \\
Free parking & 1999 & + \\
\hline
\end{tabular}

++ Crucial factor in explaining the EV market development

+ Less important factor or only important in some market niches

0 Factor which up to 2013 was not considered important

transnational routes. This means that, despite the long distances, a cross-Norway drive is a possibility for most EVs, albeit requiring frequent charging stops.

To better understand the potential for increasing competitiveness of EVs the Compett project carried out a web survey among $1721 \mathrm{EV}$ owners (members of the Norwegian EV
Fig. 3 Developments in the market and in EV policies in Norway 1997-2013

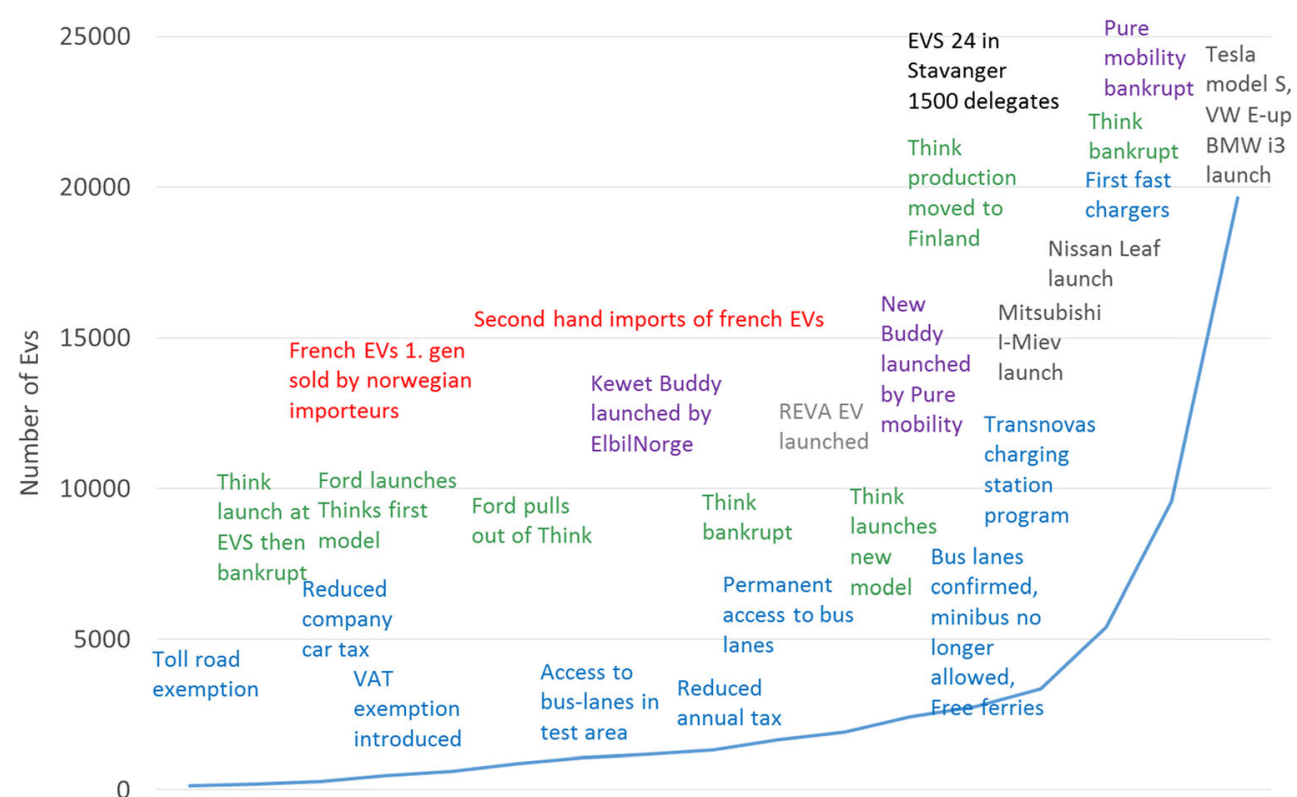

19971998199920002001200220032004200520062007200820092010201120122013 
Association) and another survey among 2241 general car owners (members of the Norwegian Automobile Association). Both surveys took place in January 2014. Norwegian EV owners value the economy of electric motoring, the environmental benefits, and most importantly; that EVs meet their transport needs [13]. They do not report large problems with having an EV and have developed various strategies before and during their travel for coping with possible range challenges. They plan better, borrow a car, use the family's second car or they drive more economically, turn off $\mathrm{AC}$ and heater or use a fast charger. $7 \%$ of respondents with several cars in the household and $20 \%$ in single-EV households report that they have experienced that some trips could not be made. However, they were not asked about how often this happened and of the importance of these trips. When looking at trip distances and stop patterns for Norwegian car drivers, cf. Section 3.2, it appears that most daily travel in Norway can be done with a BEV.

Norwegian EV owners suffer relatively little from range anxiety and are comfortable using on average $80-85 \%$ of the battery's range [13]. $65 \%$ charge their vehicle daily, $20 \%$ charge $3-5$ days per week and another $15 \%$ charge $1-$ 2 times per week at home in a garage, carport or outdoor. Public normal charging is used at least monthly by about half the EV owners, and 7-14\% use it weekly. Workplace charging is more widely used than public charging. The average annual number of fast charges per vehicle is about $14.27 \%$ use fast chargers more than once per month, and $6 \%$ are weekly users. EV-only owners use fast charging more than owners in multicar households. Normal charging at public parking spaces is usually free. Half of the respondents did not pay for fast charging, for instance because they have a Tesla with lifetime free fast charging. Although fast charging was sometimes free of charge a few years ago, all fast chargers now [9] require payment.

Almost all EV owners (87 \%) will continue to buy EVs in the future. The motivations to buy again are related to economy and incentives, environment, and the joys of EV motoring (comfort, low noise), and that it fits their needs. Some owners also state that it is the technology itself, believing it to be the future of motoring, that is important.

The Compett project has compared attitudes to EVs among EV owners and a general sample of car owners (2 241 members from the Norwegian Automobile Association (NAF) were interviewed). Figure 4 illustrates that those with experience of EVs have a rather different attitude to EVs than the general car owner. The latter group finds more disadvantages and few advantages with EVs. Therefore, it seems important to distribute knowledge of EVs in order to increase the market share. The study also shows that both media (including websites) and social networking among persons is of large importance in the diffusion process. Among the members of the NAF who own ordinary cars, $30 \%$ would consider an EV the next time they buy a car. Among those who have friends with $E V s$, the rate is much higher: $44 \%$. Further, $36 \%$ of those who own EVs state that they have friends who bought EVs after they told them about the experience.

The Norwegian EV policy, with its many incentives, long history and the establishment of Transnova, has reduced the barriers for e-mobility. Norwegians were ready to buy EVs when the big automakers started launching their models in late 2010 [11, 13], having had experience with EVs throughout the 2000s.

The Norwegian incentives are highly valued by the EV owners, and represent crucial motives for buying this type of cars. Figure 5 shows that lower operating costs is the most important factor for EV owners when buying a new vehicle, much more so than for general car owners, here represented by the NAF members, shown in Fig. 6. Lower energy cost per km is an essential part of this, but also free toll-roads and free parking could be part of this parameter. EV owners also place a higher significance on competitive price than NAF members do. In addition, reduced annual circulation tax is important for EV owners. However, both groups agree about the importance of the car being "the best car for my need."

An interesting point from this comparison of EV owners and general car owners is their very different weighing of environment and safety. Two thirds of the EV owners value that EVs are environmentally friendly while only a quarter of the general car owners do so when buying their car.

There are large regional differences in the reported advantages from the various incentives. Bus lane access is emphasised in the Oslo-region, where resulting time savings are large (up to $30 \mathrm{~min}$ ). Reduced ferry rates are more important in the coastal regions. EV owners seem to live and work in areas where they can use these facilities to a larger extent than the average car owner. However, the EV market is spreading into smaller towns and even in areas where no local incentives are at work. This fact suggests that incentives are not the only factor influencing the EV-buyer's choice, but are efficient in raising awareness and getting the market started.

In Fig. 7, each of the 428 Norwegian local municipalities is recoded with BEV market penetration (BEVs per capita) and a calculation of the value of local EV incentives. Section 6 provides more details about this calculation. Some municipalities enjoy zero or hardly any incentives (no bus lanes or toll roads, parking is already free, etc.). In others, the local value can be substantial, due, e.g., to large travel time savings from bus lane access, toll road exemptions and ferry rebates. The outliers with very high market penetration are wealthy areas with especially high benefit from access to bus lanes, or small islands with costly toll road connections to the mainland. At the other end of the spectrum, the outliers with relatively low market shares despite high value of incentives are rural areas where access to the nearest city (Trondheim) is costly. Assumingly, $\mathrm{BEV}$ incentives cannot compensate for the troublesome 
Fig. 4 EV owners $(N=1721)$ and general motorists $(N=2241)$ evaluate EVs differently
EV owners

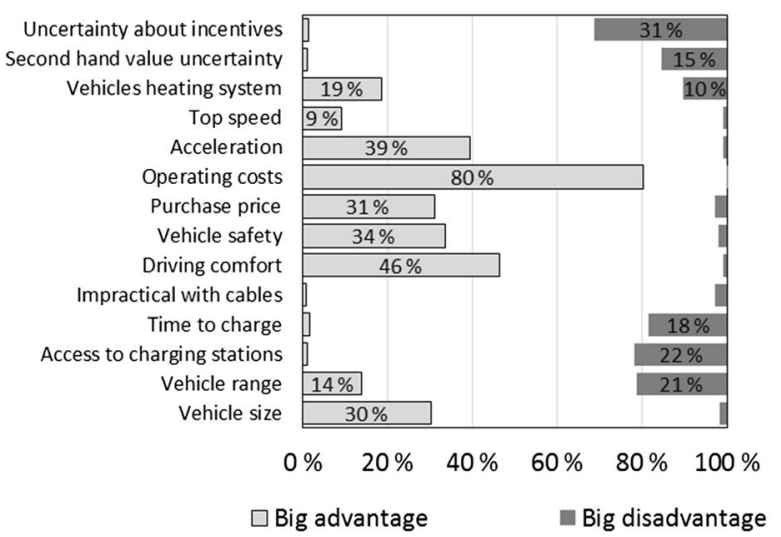

Car owners

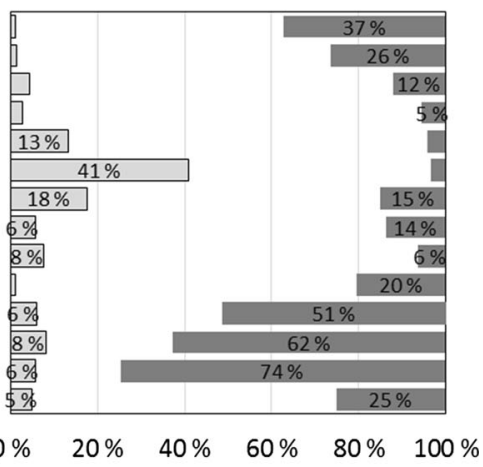

distances and ferry crossing there. The linear trend line has a fairly good level of fit $\left(\mathrm{R}^{2}\right)$ only from this bivariate relationship, which suggests that BEV market shares depend strongly on the user value of local incentives. ${ }^{2}$

\subsection{Austria}

The starting point for the launch of electric mobility on the Austrian market are support programmes, a positive tax framework, as well as the so-called pilot regions and lighthouse projects, demonstrating technological solutions and regional pilots that have generated, since the year 2008, practical experience and knowledge in Austria. However, contrary to Norway, there are is no VAT exemption and there are almost no non-monetary incentives such as the use of bus lanes.

In Austria, the number of e-vehicles in the yearly stock is rising rapidly (Fig. 8), but of course not comparable to other countries like Norway. The share of E-vehicles compared to the total stock (4.7 million cars) is currently around $0.06 \%$.

\subsubsection{Incentives for e-mobility}

Electric vehicles are exempted from the purchase tax and the annual motor vehicle tax, resulting in about EUR 4000 savings over 5 years. Financial incentives for private users are only given from the nine Austrian federal states: the subsidy schemes differ a lot but can offer grants up to EUR 4000 per evehicle. Also insurance companies offer discounts from 10 to $20 \%$ for e-vehicles. Only a few cities offer free parking for evehicles (not Vienna).

Financial incentives and purchase tax credits for companies and communities are offered within the national climate protection programme "klima:aktiv".

\footnotetext{
${ }^{2}$ If the outliers are excluded then the slope and $\mathrm{R}^{2}$ of the trend line remain relatively unchanged. Purchase incentives are not included in the figure since they are equal across the country.
}

The rates are staggered according to the type of vehicle introduced, the level of $\mathrm{CO}_{2}$ reduction achieved and the amount of renewable energy used for new cars with alternative propulsion systems: e.g. a tax credit of EUR 500 for hybrid vehicles.

Up to EUR 4000 are granted for purchasing EVs, if powered with renewable energy, otherwise only EUR 2000. Since 2013, also the purchase of Plug in Hybrid vehicles and Extended Range Electric vehicles are eligible within the new funding regime and there are subsidies from EUR 500-3000 available, depending on the level of $\mathrm{CO}_{2}$ reduction and the amount of renewable energy used. E-bikes are granted EUR 200 , or EUR 400 when powered with green electricity. The purchase of E-scooters is subsidised with EUR 250-500.

klima:aktiv has proven to be an important tool for e-mobility: Around 10,000 electric vehicles (primarily e-bikes/escooters and light-weight community e-vehicles) and over 1000 additional electric charging points were funded within the programme. The corresponding reduction of $\mathrm{CO}_{2}$ emissions amounts to 23,802 tonnes/a. Within the years 20072013, an overall support volume of klima:aktiv for the conversion of fleets to alternative fuels and propulsion systems of EUR 14.2 m triggered EUR 106 m of investments and generated and secured 1200 new "green jobs" [22].

\subsubsection{Pilot regions for E-mobility}

Within the Austrian Climate and Energy Fund, the introduction of e-mobility is promoted by $\mathrm{R} \& \mathrm{D}$ projects and the pilot regions for e-mobility. These regions focus on electric vehicles powered by renewable energy sources and the integration of "vehicle use schemes" in combination with the public transport system. Users within the pilot regions pay a monthly "mobility rate" which includes not only the electric vehicle, but also the use of public transport.

To date, seven pilot regions have been established reaching about 3.5 million people or $40 \%$ of the population of Austria 
Fig. 5 Degree of importance of factors and incentives related to buying a new vehicle as seen by EV owners in Norway $(n=1721)$ Percent

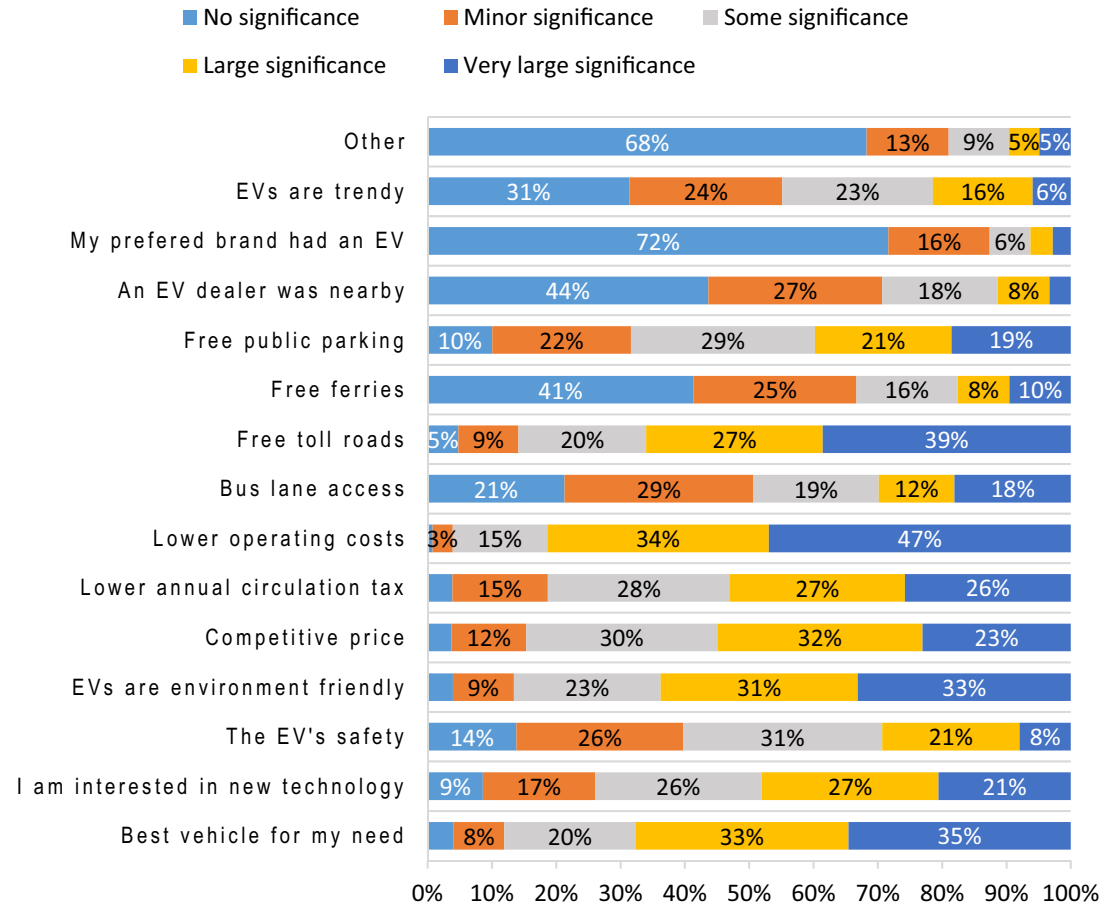

(Fig. 9). These model regions are the major drivers for the establishment of charging infrastructure in Austria:

(1) in 2009 the Vorarlberg/Rhine valley region (VLOTTE Project) with 360 e-cars/LDVs and 120 charging stations; mobility services contracts including leasing of ecars, railway/public transport pass, car sharing and free charging; provision of $20 \mathrm{~m}^{2}$ photovoltaic power for each e-car;

(2) in 2010 the Greater Salzburg Area with 100 e-cars and 750 e-bikes; ElectroDrive ,e-mobility with the public transport pass": leasing/purchasing concept for e-bikes, e-scooters, Segways and e-cars; free charging with „green electricity“ (photovoltaic; hydro-power);
(3) the urban agglomeration of Graz: e-mobility Graz; goal 500 e-cars, 1200 e-bikes, 140 public charging points; emobility services packages for large fleet operators (vehicles, public transport, charging stations);

(4) Vienna metropolitan area; e-mobility on demand; goal of 500 cars, 100 charging points; multi-modal mobility and public transport pass with focus on commuters and fleet operators; renewable energy for 2000 e-cars;

(5) e-mobility in Lower Austria: 49 municipalities, use of electric vehicles by commuters, promising last mile solutions;

(6) The Austrian Post e-mobility delivery services in Vienna metropolitan and 12 regional distribution centres: 200 electric utility vehicles for postal mail delivery
Fig. 6 Degree of importance of factors related to buying a new vehicle as seen by general car owners in the Oslo-Kongsberg region $(n=2241)$. Percent

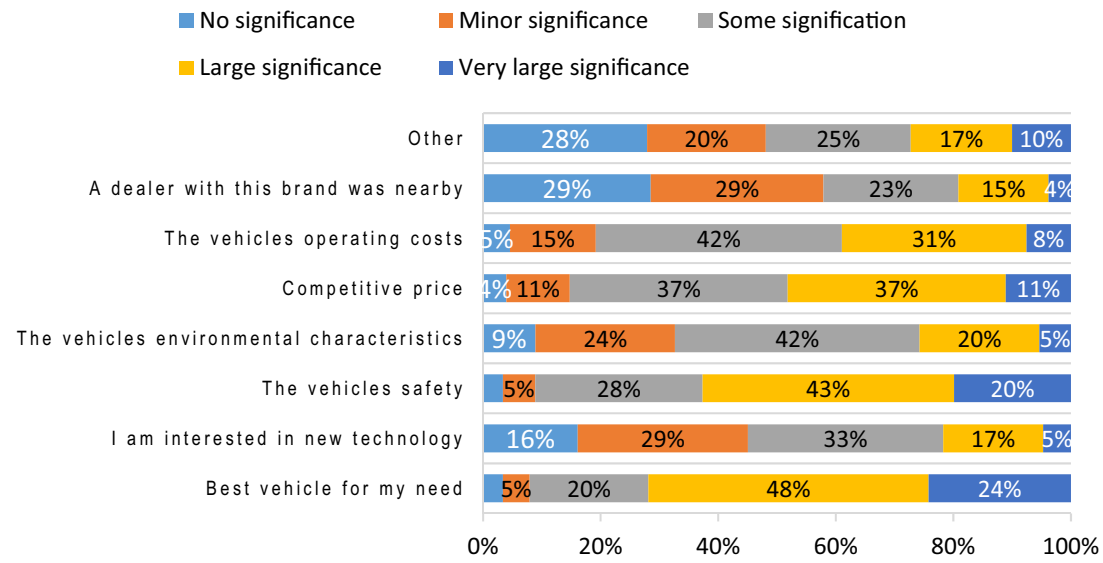


Fig. 7 BEVs per 1000 capita in Norwegian municipalities, compared with the annual value (in $€$ ) of local $\mathrm{EV}$ benefits

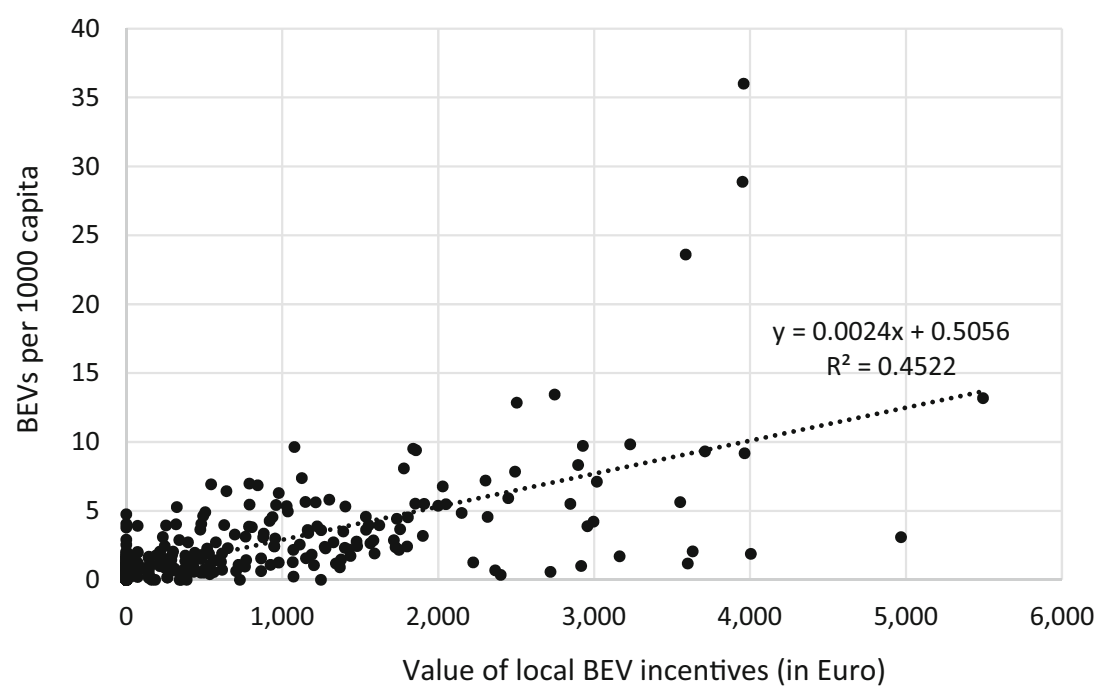

(7) e-log in the City of Klagenfurt; promising e-logistics solutions with 200 electric vehicles (goal) with focus on SMEs.

As a next step, particular attention will be given to linking the different pilot regions by facilitating interoperability of electric vehicles and charging stations. For all the pilot regions particular attention is given to further integration of e-mobility and public transport, the facilitation of multi-modal solutions and interlinking the different pilot regions to facilitate interoperability of electric vehicles and the charging infrastructure.

Lessons learned were drawn from accompanying research including an analysis of user feedback in the pilot regions. The lessons learned can be pointed out as follows:

- $\quad 120-150 \mathrm{~km}$ range of e-vehicles is sufficient for daily journeys ( $50 \%$ of car trips $<5 \mathrm{~km}$ ); combined mobility services provide solutions for long distance.

- Environmental advantages of e-vehicles are important

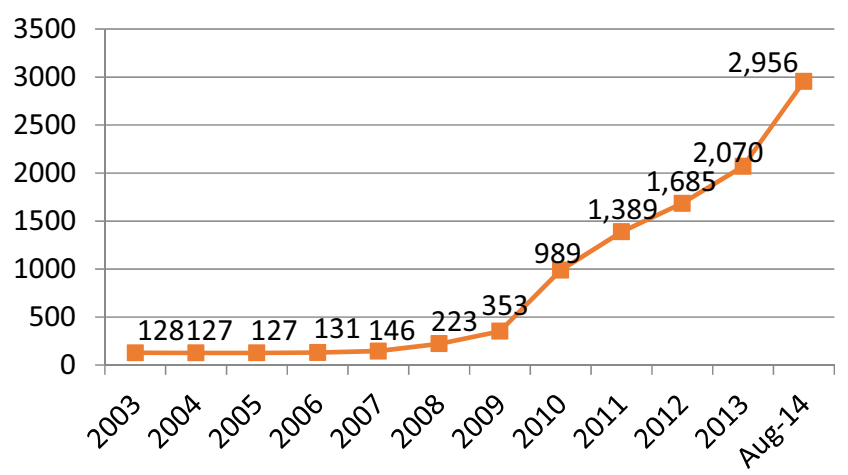

Fig. 8 EV development in Austria from 2003 to August 2014
- Preferential charging with green electricity from $100 \%$ renewable energy sources (photovoltaic, wind and water power, biomass)

- 80 to $90 \%$ of slow charging at home/office with ordinary power plugs ( $2.3 \mathrm{~kW}$ power). Re-charging of batteries is only needed every third day

- Public charging stations are psychologically important (limited e-vehicle range), but little used, except for fast, high power $(55 \mathrm{~kW})$ charging stations

- Despite available subsidies and tax reductions, the total costs of ownership of e-cars are, for most car models, still considerably higher in Austria compared to conventional cars: $3000-13,000$ EUR over a period of 8 years. Thus financial support is crucial for a further market development at present

\section{Cost of incentives and optimal phaseout}

\subsection{Cost and value of incentives}

Subsidy cost and revenue loss to local and central governments can amount to substantial budgetary stress. Successful EV policies may also cause other consequences like reduced fuel tax revenues, congested bus lanes, reduced parking availability, reduced walking and cycling, etc. Some governments have therefore capped their incentives already at the launch of the incentive either up until a fixed future date, until a certain level of goal achievement is reached, or until an earmarked budget is depleted. The Norwegian government declared in 2012 that their generous package of benefits will stay in place till the end of year 2017 or till 50,000 BEVs are registered, whichever comes first (Norway reached 


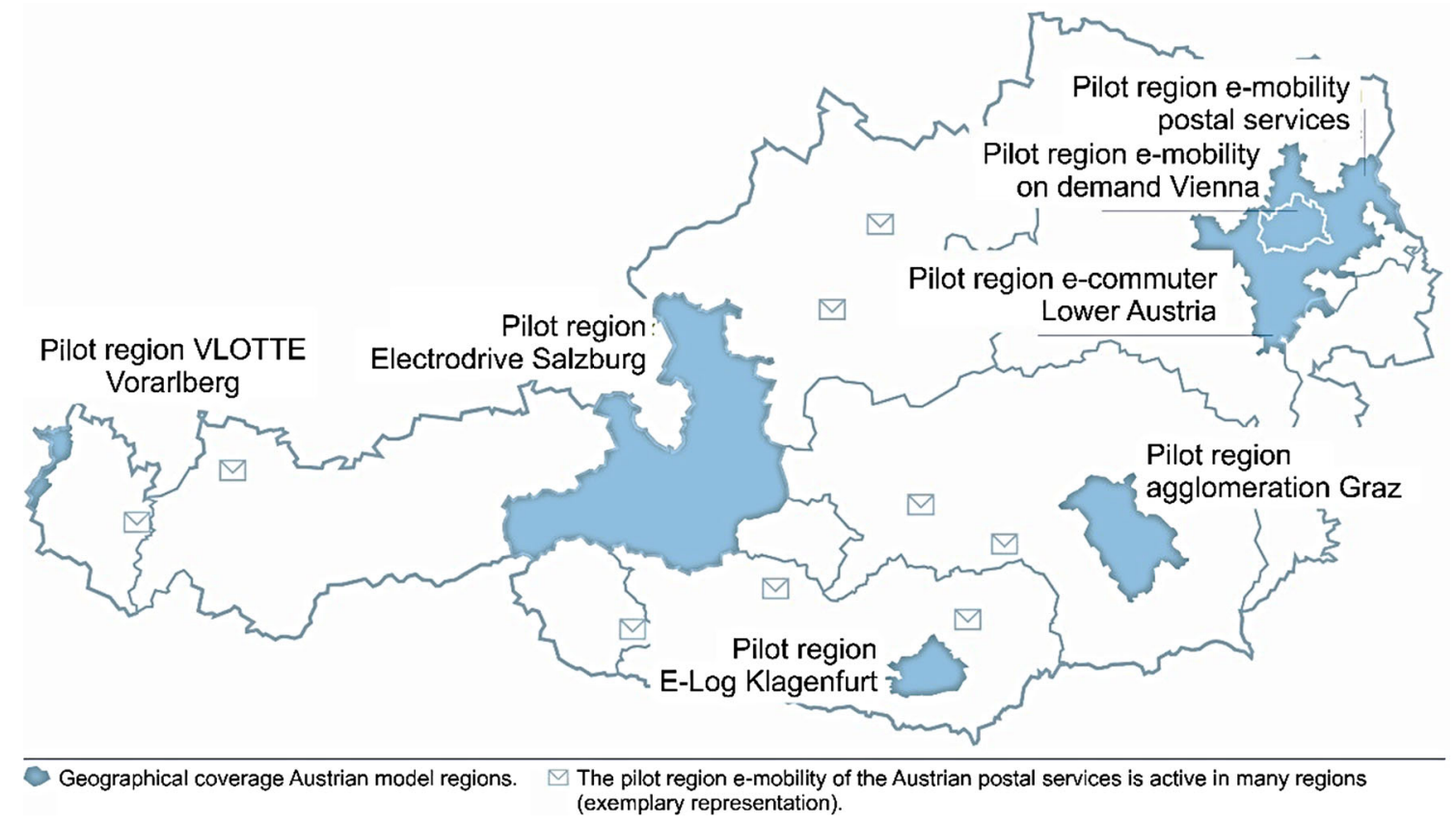

Fig. 9 Austrian pilot regions for E-mobility

50,000 BEVs in April, 2015 ${ }^{3}$ ). However, when the incentives where introduced, c.f. Table 2 , no conditions or detailed procedure for termination were specified, and changes may now require revisions to national laws.

For Norway, Fridstrøm and Alfsen (ed. [15]) have estimated that EV incentives represent lost revenues from purchase tax, annual tax, VAT exemption and toll road exemption lie in the region of EUR $0.18-0.25 \mathrm{bn}$. The VAT exemption alone costs M€41.3 annually [11]. The total picture includes also costs of local incentives, lost fuel taxes, increased electricity taxes, etc.

A life cycle calculation shows that Norwegian EV incentives cost $€ 10.500$ per saved ton of $\mathrm{CO}_{2}$, while the going price on the European $\mathrm{CO}_{2}$ permit market is about $€ 5$ per ton [19]. Their study has been contested among other things for using unrealistic annual mileage assumptions for EVs and car ownership and unrealistic usage patterns for local incentives, and for solely focusing on the short term cost of $\mathrm{CO}_{2}$-mitigation, ignoring the long term effects of getting the market cycle of cost reductions and technology improvements on the way. Fridstrøm and Alfsen [15] show that the Norwegian EV fiscal incentives in fact have positive net welfare effect for society. Additionally, electricity in Norway is mostly hydropower. Using this for transport is a $\mathrm{CO}_{2}$ neutral solution, opposed to other situations, where the place of $\mathrm{CO}_{2}$ generation is only changed. In any event, to move transport

\footnotetext{
${ }^{3}$ Shortly after that, in June 2015, the Norwegian government declared that all BEV incentives will be prolonged, but annual tax exemption will be phased out in 2018 and local authorities may choose away bus lane access and free parking.
}

energy use from private consumption (gasoline) to the $\mathrm{CO}_{2}$ permit market (electricity) will contribute to greenhouse gas reductions [15].

As part of the Compett project, Norwegian EVowners have been asked to identify the various local user benefits they enjoy when using their EVs. From this, we have calculated the annual average economic value of the incentives for the average EV driver. In Table 3, the results have been scaled up to the size of the EV fleet in April 2014, 25000 vehicles. The economic value is $€ 1900$ per vehicle and $€ 48 \mathrm{~m}$ for the total fleet per year. This rests on the following assumptions:

- Based on the National Value of Time study, the value of time saved in queue due to the access to bus lanes on rush hour trips to work is $€ 33.6$ per hour.

- The value of the toll-road exemption is estimated by combining respondents' information about usage of toll-road,

Table 3 Calculated average values per year of different local incentives per car and for total fleet in Norway Total fleet in Norway=25 000 EV's in April 2014

\begin{tabular}{lll}
\hline Incentive & $\begin{array}{l}\text { Value per car } \\
\text { Euros/year }\end{array}$ & $\begin{array}{l}\text { Value for EV fleet } \\
\text { million Euros/year }\end{array}$ \\
\hline Bus lane & 940 & 24 \\
Toll-road & 434 & 11 \\
Free parking & 398 & 10 \\
Free ferries & 145 & 4 \\
Total & 1928 & 48 \\
\hline
\end{tabular}

Euros/year based on an exchange rate of NOK8.3 per Euro 
and the cost of the toll-road that they could be using, given maximum available rebates (which daily commuters will be entitled to). This approach is associated with some uncertainties. The average reflects the fact that not all EV owners pass toll roads. The regional differences are very large.

- The value of free parking is calculated as a weighted average of EV owners' stated weekly saving. This total figure corresponds well with findings of a forthcoming study of this incentive [8]

- The reduced ferry price is a very rough estimate based on the ferry rate savings in the municipality the owner belongs to and how they responded in the questionnaire about this incentive's importance

As described above, there are large regional differences in the advantages the users report from the various incentives. The share of EV owners using both free toll road and access to bus lanes more than twice a week when driving to work is only $33 \%$. In addition, $26 \%$ uses toll roads only and $6 \%$ bus lanes only.

Bus lane access will be a benefit to society as long as spare capacity is used without delaying buses. The toll-road incentive leads to lower income for the toll-road company. This company has a loan that is used to build roads and to support public transport in different ways. When income is reduced, either the rate per paying vehicle must be increased, or the period of payment prolonged. In both cases there is a cross subsidy between payers and non-payers. Free ferries are different from free toll-roads. The ferry cost should cover the marginal cost of transporting the vehicle and persons in the vehicle. If fewer pay, the rate per paying vehicle is increased or the subsidy from the province or government must increase. Free parking means that municipal income per parking space is reduced, that fewer parking spaces are available to other paying users, and reduced circulation. The cost of the free parking incentive for municipalities may thus exceed the value of the incentive for the EV owner.

\subsection{Cost-effective phase-out}

The introduction of EVs and departure from ICEs clearly require large subsidies and investments as well as a political commitment. However, the goal is to establish a selfsustaining market that could eventually thrive in a future time without public sector support. The question is, what is the size of a self-sustaining market and how to adjust different subsidies as the market for EVs grows in a manner that would not harm the take-off of the EV market. With the growth of the EV market the different factors that create that gap in the price of a typical EV vehicle and a typical ICE vehicle decreases. Figure 10 gives a schematic illustration of the principle. (Here, we only look at EV incentives and not at offsetting tax

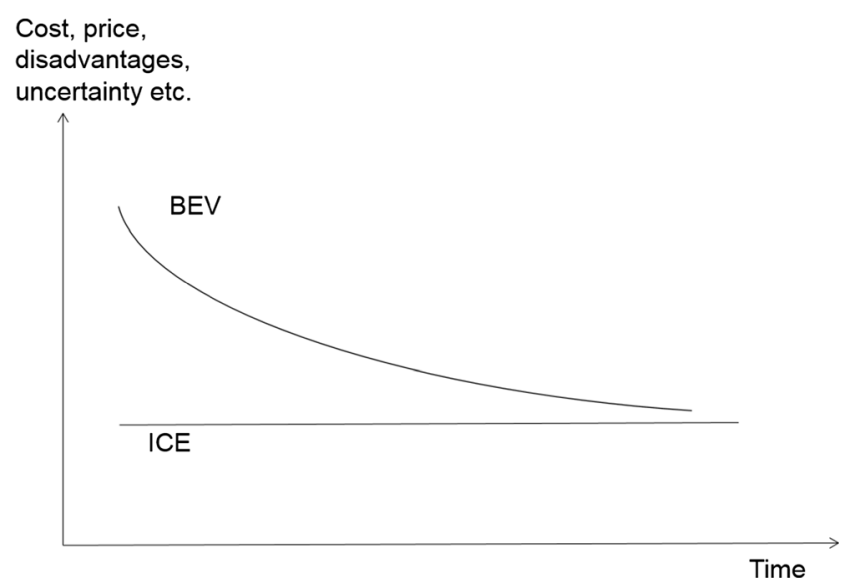

Fig. 10 As EV disadvantages fall, less incentives are needed in order to make EVs competitive

increases in alternative markets.) In the early years, the industry suffers from primitive and expensive technology, consumers face uncertainties with respect to second-hand market value, range, safety, etc., and a vast majority of the population is largely unaware of the EV market characteristics compared to that of ICEs (see Fig. 4). The gap between the two technologies decreases with the decrease in the size of these problems over time. Hence, the amount of the incentives should also decrease. It will eventually become inefficient and ineffective to maintain the level of incentives. Which incentives should be first abolished or reduced in size? Examples of these incentives in Norway, which have been important in different municipalities for the take-off of the EV market, are exceptions from road or ferry tolls, parking charges and VAT exemption. Forthcoming Serapis modelling will address this by identifying the least cost-effective and most detrimental policies. Table 2, above, already hints to the various incentives' effectiveness, but do not consider cost-efficiency.

\section{Conclusions, policy recommendations and discussion}

The main conclusion of this paper is that successful market uptake and expansion of electric vehicles is the result of massive, expensive and combined policies. The high market penetration in Norway has been achieved through a broad package of incentives, which include reductions in the cost differences between conventional vehicles and e-vehicles, preferential treatment with respect to parking, road charging exceptions, access to bus lanes, a strategy for charging stations which is accompanied by generous government support, and technological advances. In tandem with this, the Norwegian growth is the result of diffusion mechanisms such as increasing awareness of the technology and products. With the continuation of current incentives and a well-communicated plan for gradual changes, the market share of EVs will probably 
continue to increase. The fact that these policies have state backing and apply to all parts of the country has probably reduced the perceived risk for market players like car importers. The policies are clear and predictable. Compared with Norway, Austria has followed a path which relies less on market mechanisms and which is more top-down in the sense that much responsibility and initiative lies with the e-mobility regions rather than general incentives in the market. The Austrian EV market has evolved in a similar fashion to Norway (compare Figs. 3 and 8), but the size of the Norwegian market is considerably larger - by a factor of about 10 .

The differentiated use of incentives and our EV user surveys point to an important aspect of the Norwegian success. Since the users have different needs, national and local stakeholders and the industry should use a broad package of incentives in marketing this new technology in order to speed up its diffusion. In addition to addressing different local barriers to EV use, the package of incentives sums to a forceful and reinforcing combination market stimuli.

For countries which are still in an early phase of promoting EVs, like Austria, this paper has shown that the potential for EV uptake is promising. EVs are already a real option for the majority of peoples' everyday trips and trip chains. However, the EVs' relative disadvantages to the ordinary car must be reduced by applying incentives in the initial market launch phase, and the lack of knowledge in the population at large must be addressed. We have illustrated the importance of information in the process of dissemination of new technology by the fact that EV owners in urban areas, being the pioneer areas, have influenced more friends to buy an EV after them than EV owners in other areas have. People with family or acquaintances who own an EV are much more likely to consider an EV themselves. Technological diffusion is a process which takes place in a social system where communication is a crucial element. Key elements in this communication process are, 1) how the new technology is perceived with respect to relative advantages and compatibility with user needs and societal norms; and 2) observability and visibility, i.e. opportunity to experience the products. The first groups to be targeted are the early users (Innovators) and the early adopters. They are: urban dwellers, relatively young, mostly men, with high education and income, and belong to multicar households.

Finally, it is worth highlighting the importance of costeffective policies. Most EV incentives have a high cost. Inefficient policies should be avoided, including those which may be unduly harmful to other parts of society, like, e.g., bus lane access which could severely delay buses if not implemented properly. Cost-effective policies should be the first to be introduced, and the last to be withdrawn. An important area for further study is, therefore, to establish robust models and empirical evidence of how the different incentives affect market shares.
Acknowledgments This paper is a result of the project Compett (Competitive Electric Town Transport), financed jointly by Electromobility+, Transnova and The Research Council of Norway, FFG of Austria and The Ministry of Science, Innovation and Higher Education (Higher Education Ministry) in Denmark.

The Compett project is a co-operation between The Institute of Transport Economics in Norway, The Austrian Energy Agency, The University College Buskerud in Norway, Kongsberg Innovation in Norway and the Danish Road Directorate. More information: www.compett.org

Open Access This article is distributed under the terms of the Creative Commons Attribution 4.0 International License (http:// creativecommons.org/licenses/by/4.0/), which permits unrestricted use, distribution, and reproduction in any medium, provided you give appropriate credit to the original author(s) and the source, provide a link to the Creative Commons license, and indicate if changes were made.

\section{References}

1. ACEA (2014) Overview of purchase and tax incentives for electric vehicles in the EU. 01.04.2014. http://www.acea.be/uploads/ publications/Electric_vehicles_overview_2014.pdf Accessed Sept 2014

2. Asphjell A, Asphjell Ø, Kvisle H H (2013) (in Norwegian), Elbil på norsk. Transnova. ISBN 978-82-7704-142-1

3. Assum T, Kolbenstvedt M, Figenbaum E (2014) The future of electromobility in Norway - some stakeholder perspectives. TØI report 1385/2014

4. Budget agreement (2001) Agreement in the Storting (the Norwegian parliament) about the national budget for 2001 . https://www.regjeringen.no/nb/dokument/dep/fin/statsbudsjettet/ budsjett-2001/budsjettavtale-for-statsbudsjettet-for-2/id411925/

5. Campell AR, Ryley T, Thring R (2012) Identifying the early adopters of alternative fuel vehicles: a case study of Birmingham, United Kingdom. Transp Res A 46:1318-1327

6. Econ analyse (2006) Elbileiernes reisevaner (Travel behaviour of EV owners) Rapport 2006-040. Oslo

7. Electric Vehicles Initiative (2013) Global EV Outlook. Understanding the Electric Vehicle Landscape to 2020. April, 2013. Clean Energy Ministerial and International Energy Agency

8. Fearnley N (2014) Parking revenues lost due to mandatory free public parking of electric vehicles. TOI report 1340/2014

9. Fearnley N, Pfaffenbichler P, Figenbaum E, Jellinek R (2015) Evehicle policies and incentives: assessment and recommendations. Compett deliverable D5.1. TØI report 1421/2015

10. Figenbaum E, Assum T, Kolbenstvedt M (2015) Electromobility in Norway - experiences and opportunities. Res Transp Econ. doi:10. 1016/j.retrec.2015.06.004

11. Figenbaum E, Kolbenstvedt M (2013) Electromobility in Norway experiences and opportunities with Electric Vehicles. TOI report $1281 / 2013$

12. Figenbaum E, Kolbenstvedt M (2015, forthcoming) Motives and experiences of owners of electric vehicles in Norway. The path to pure electric car use - motives and experiences. Submitted to Environmental innovation and societal transitions

13. Figenbaum E, Kolbenstvedt M, Elvebakk B (2014a) Electric vehicles - environmental, economic and practical aspects: As seen by current and potential users. TOI report 1329/2014

14. Frey H, Mayerthaler A, Pfaffenbichler P (2011) Stadtauto e-Mobil Chancen und Risiken für Wien, H. Zukal (Hrg.); Institut für Verkehrswissenschaften - Forschungsbereich für Verkehrsplanung und Verkehrstechnik, Technische Universität Wien, Beiträge zu einer ökologisch und sozial verträglichen Verkehrsplanung 
15. Fridstrøm L, Alfsen K (2014) Norway's path to sustainable transport. ТØI rapport 1321/2014. https://www.toi.no/getfile.php/ Publikasjoner/T\%C3\%98I\%20rapporter/2014/1321-2014/13212014-elektronisk.pdf

16. Hjorthol R (2013) Attitudes, ownership and use of Electric Vehicles - a review of literature. TØI Report 1261/2013

17. Hjorthol R, Vågane L, Foller J, Emmerling B (2013) Everyday mobility and potential use of Electric Vehicles. TOI report $1329 / 2014$

18. Hjorthol R, Vågane L, Foller J, Emmerling B (2014) Everyday mobility and potential use of Electric Vehicles. TØI report $1352 / 2014$

19. Holtsmark B, Skonhoft A (2014) The Norwegian support and subsidy policy of electric cars. Should it be adopted by other countries?; NTNU Working paper 2/2014; http://www.ntnu.edu/ documents/140152/622066862/Skonhoft_2014.pdf/f3e76873f739-42ae-9fff-dee25ed0f6cd

20. Hoogma R, Kemp R, Schot J, Truffer B (2002) Experimenting for sustainable transport: the approach of strategic niche management. Spon Press, London, ISBN-13: 978-0415271172

21. Jacobsen S, Bergek A (2011) Innovation system analysis and sustainability transitions: contributions and suggestions for research. Environ Innov Soc Transit 1(1):41-57

22. klima:aktiv mobil Förderungsprogramm (2014) Leistungsbericht und neue Akzente (Outlook and Achievements); http://www. klimaaktiv.at/publikationen/mobilitaet/erfolgsbilanz.html. Accessed Apr 2015

23. Ministry of Finance (1989) National budget 1990, White paper to the parliament. St.prop. 1, 1989-1990

24. Moch P, Yang Z (2014) Driving electrification. A global comparison of fiscal incentive policy for Electric vehicles. White paper. ICCT. The International Council on Clean Transportation, Washington

25. Pan et al (2012) Urban characteristics attributable to density-driven tie formation. NetSci 2012, Evaston, IL, June 20th, 2012

26. Parsons T (1951) The social system. The Free Press, New York
27. Pfaffenbichler P, Castro A, Emberger G, Frey H, Kloess M, Rezanina R, Krutak R (2012) SOL - Studie für die Organisation der zukünftigen Ladeninfrastruktur für E-Fahrzeuge in Österreich. Notwendige Anzahl und wirtschaftliche Standorte, Oesterreichs EWirtschaft, Wien

28. Pfaffenbichler P, Emmerling P, Jellinek R, Krutak R (2009) PreFeasibility-Studie zu „Markteinführung Elektromobilität in Österreich“, Österreichische Energieagentur, im Auftrag von Bundesministerium für Verkehr, Innovation und Technologie (bmvit), Abteilung Mobilität und Verkehrstechnologien (III/I4). Wien. http://www.bmvit.gv.at/innovation/downloads/ markteinfuehrung_elektromobilitaet1.pdf

29. Pierre M, Jemelin C, Louvet N (2011) Driving an electric vehicle. A sociological analysis on pioneer users. Energy Effic 4:511-522

30. Ramjerdi F, Fearnley N (2014) Risk and irreversibility of transport interventions. Transp Res A 60:31-39

31. Renner S, Baumann M, Jamek A, Lang B, Pfaffenbichler P (2010) Visionen 2050 - Identifikation von existierenden und möglichen zukünftigen Treibern des Stromverbrauchs und von strukturellen Veränderungen bei der Stromnachfrage in Österreich bis 2050. Österreichische Energieagentur im Auftrag von Österreichs Energie, Wien

32. Rødseth J (2009) Spørreundersøkelse om bruk av og holdninger til elbiler i norske storbyer (survey of use and attitudes toward EV in larger cities in Norway). Notat. Asplan Viak AS, Trondheim

33. Rogers E M (1962) Diffusion of innovations. ISBN 0-612-62843-4. Glencoe Free Press

34. Shahan Z (2014) Electric vehicle market share in 19 countries. http://www.abb-conversations.com/2014/03/electric-vehiclemarket-share-in-19-countries/

35. Transport for London (2010) Electric vehicle market development. Mayor of London

36. van den Bergh JC, Truffer B, Kallis G (2011) Environmental innovation and societal transitions: introduction and overview. Environ Innov Soc Transit 1(1):1-23

37. Wikipedia (2014) Government incentives for plug-in electric vehicles. Accessed 28 Aug 2014 